\title{
Optimizing Nutrient Use Efficiency and Returns from Soybean Production under Smallholders in Three Agro-Ecologies of Malawi
}

\section{Moses Munthali ${ }^{*}$, Patson Nalivata2 ${ }^{2}$ Wilkson Makumba ${ }^{3}$, Emmanuel Mbewe $^{2}$, Hastings Manase ${ }^{2}$, George Oduor ${ }^{4}$, Martin Macharia ${ }^{4}$, Kaizzi Kayuki ${ }^{5}$}

${ }^{1}$ Chitedze Agricultural Research Station, Lilongwe, Malawi

${ }^{2}$ Lilongwe University of Agriculture and Natural Resources, Bunda Campus, Lilongwe, Malawi

${ }^{3}$ Department of Agricultural Research Services, Lilongwe, Malawi

${ }^{4} \mathrm{CAB}$ International Africa, Nairobi, Kenya

${ }^{5}$ National Agricultural Research Laboratories, Kampala, Uganda

Email: *munthalimw@yahoo.co.uk

How to cite this paper: Munthali, M., Nalivata, P., Makumba, W., Mbewe, E., Manase, H., Oduor, G., Macharia, M. and Kayuki, K. (2017) Optimizing Nutrient Use Efficiency and Returns from Soybean Production under Smallholders in Three AgroEcologies of Malawi. Agricultural Sciences, 8, 801-815.

https://doi.org/10.4236/as.2017.88059

Received: July 13, 2017

Accepted: August 15, 2017

Published: August 18, 2017

Copyright (c) 2017 by authors and Scientific Research Publishing Inc. This work is licensed under the Creative Commons Attribution International License (CC BY 4.0).

http://creativecommons.org/licenses/by/4.0/

\begin{abstract}
Field trials were conducted to determine the economically optimum fertilizer rates for soybean production and for optimizing net profits in Dedza, Lilongwe and Salima Districts of Malawi. The effects of PK fertilizer rates on rain use efficiency (RUE), harvest index, agronomic use efficiency of phosphorous (AEP) and potassium (AEK), and value cost ratio (VCR) were evaluated. The applied diagnostic PK fertilizer rates significantly improved soybean grain yields, harvest index, rainwater use efficiency, AEP, AEK and returns to fertilizer use expressed as value cost ratio (VCR). However, the results differed significantly $(\mathrm{P}<0.01)$ among the three agro-ecological zones. The VCR values indicated that the most economical and profitable fertilizer rate was $7.5 \mathrm{~kg} / \mathrm{ha} \mathrm{P}$ in Salima, Dedza and Lilongwe. The lowest economical and profitable NP fertilizer rate was $22.5 \mathrm{~kg} / \mathrm{ha} \mathrm{P}$ plus $20 \mathrm{~kg} / \mathrm{ha} \mathrm{K}$ for Dedza and Lilongwe and $15 \mathrm{~kg} / \mathrm{ha} \mathrm{P}$ plus $30 \mathrm{~kg} / \mathrm{ha} \mathrm{K}$ for Salima District. All the VCR values obtained from applying different $\mathrm{PK}$ fertilizer nutrient rates were above two implying that all the applied fertilizer rates had a good value of returns to adequately cover against any risks associated with using fertilizers at smallscale under smallholder farms with inadequate financial resources. The results also presented different available NP fertilizer application rate options for maximizing profits for the financially constrained smallholder farmers.
\end{abstract}

\section{Keywords}

Soybean, Net Returns, Economically Optimum Rates, Agronomic Use 
Efficiency of Phosphorous and Potassium, Nutrient Combination, Value Cost Ratio

\section{Introduction}

Soybean (Glycine max (L.) Merr.) is one of the most important crops grown in Malawi and the crop is well adapted for production in almost all agro-ecological zones of the country. It is a source of food and income for most farmers in the country [1]. In addition, it provides many advantages in sustainable cropping systems [2], including an ability to fix atmospheric nitrogen $\left(\mathrm{N}_{2}\right)$ via symbiotic $\mathrm{N}_{2}$ fixation and, hence, alleviates the need to apply large amounts of nitrogen fertilizer [3] Although soybean crop is an important crop, its production under smallholder farms is still low with yields of $40 \%$ less $(800 \mathrm{~kg} / \mathrm{ha})$ on average against the potential yield of $2000-2500 \mathrm{~kg} / \mathrm{ha}$ [4]. Research studies on improving soybean crop production have concentrated mainly on breeding work which has led to the release of high yielding improved soybean varieties. The current low grain yields of soybean under smallholder farms are due to a number of production challenges or constraints that include primarily poor soil fertility.

Currently, in Malawi there have been no economically recommended optimum fertilizer rates for soybean grain yield production in different agro-ecological zones. Existing fertilizer recommendations also focus mainly on food security crops such as maize and soybean has been neglected. Since soybean can fix nitrogen from the atmosphere through symbiotic relationship with rhizobium bacteria, it was assumed that soybean does not require much fertilizer for grain yield production. This means that there has been very little replacement of the nutrients such as $\mathrm{P}, \mathrm{K}$ and micro-nutrients mined from the soil (i.e. removed through harvest). This has led to negative balance of the soil nutrient between what crops uptake from the soil and what is put back into the soil [5].

Soil fertility status for the country shows that Malawi soils are highly weathered and low in OM, N, P, K and other micronutrients [6]. Consequently, there has been decrease in crop yield including soybean under farmers' field conditions. This calls for a need to use fertilizers to replace the depleted soil nutrients and to reverse the negative nutrient balance in the soil. Soybean has been mostly cultivated in the country without use of application of chemical fertilizers except use rhizobium inoculants to enhance nitrogen fixation. As such most critical nutrients such as $\mathrm{P}, \mathrm{K}$ and micro-nutrients have never been supplied to soybean production to achieve optimum grain yields.

Work done by many researchers has shown non soybean grain yield response to applied N [7] [8] [9]. In Zambia and Nigeria there has been a mean soybean grain yield response of less than 100 and $30 \mathrm{~kg} /$ ha respectively due to applied $\mathrm{N}$ [7]. However, application of $\mathrm{P}$ and $\mathrm{K}$ has demonstrated to increase soybean grain yield and enhances soybean $\mathrm{N}$ fixation [10]. A mean soybean grain yield increase 
of $840 \mathrm{~kg} / \mathrm{ha}$ and $60 \mathrm{~kg} / \mathrm{ha}$ was reported by applying $15 \mathrm{~kg} / \mathrm{ha} \mathrm{P}$ and $10 \mathrm{~kg} / \mathrm{ha} \mathrm{K}$ in Uganda [11]. While in Zambia, Ethiopia, Nigeria, Ghana and Guinea Savanna of Nigeria, there were 400, 260, 570 and $260 \mathrm{~kg} /$ ha grain yield increase respectively in response to applied $15 \mathrm{~kg} / \mathrm{ha} \mathrm{P}$ [7] [12] [13]. In Nigeria there was also a positive soybean yield response of $200 \mathrm{~kg} / \mathrm{ha}$ and $100 \mathrm{~kg} / \mathrm{ha}$ due to application of $\mathrm{Zn}$ and B respectively [7]. However, in Malawi there has been not much research work done looking at optimizing soybean grain yield response due to application of different fertilizer elements and rates.

The Malawi Government policy encourages uses of fertilizers to improve crop production in the country. However, the current fertilizer use by smallholder farmers in crop production to replace the depleted nutrients is still very low. Currently less than $50 \%$ of smallholders in the country use fertilizer, and about $70 \%$ use less than $50 \mathrm{~kg} / \mathrm{ha}$ [14]. The low fertilizer usage has been partly due to the prevailing poverty and constrained by their financial ability. Consequently, there has been declining soybean grain yield production per unit area below the potential soybean grain yields in the country. The other challenge is that the current fertilizer recommendations only assume that smallholder farmers have the ability to buy all the amounts of fertilizer to achieve the recommended fertilizer rates. It does not consider the smallholder farmers that are financially resource constrained and how best to optimize production and profits from their few available resources. However, from the available few resources the smallholder farmers have they can increase or maximize profits in soybean grain yield production. Although there are many different fertilizer types available on the market giving a wide range of choices to be used by smallholder farmers, there are no recommended nutrient combination rates that are economically optimum for soybean grain production in Malawi. Furthermore, there are no fertilizer optimization decision tools that can be used to advise farmers on which types of fertilizer to buy and in what quantities to apply based on their available limited financial resources. The simple approach to help smallholder farmers to maximize profits is to make proper decision based on what type of fertilizers to buy, in what combinations and in what quantities to apply to achieve optimum soybean production. This approach requires use of fertilizer optimization tools. Efforts are being made to develop fertilizer optimization tool under Optimizing Fertilizer Recommendation for Africa (OFRA) project. This study was carried out with the goal of determining the economically optimum fertilizer rates for soybean in different agro-ecological zones of Malawi. The specific objectives of the study are 1) to evaluate the effect of different PK fertilizer rates on grain yield, harvest index, rain use efficiency, and agronomic phosphorous and potassium use efficiency and 2) to determine profit returns to PK fertilizer use in soybean production. The main hypotheses being tested was application of PK fertilizer rates to soybean did not improve soybean grain yield production and optimize profit gains under smallholder farming. 


\section{Materials and Methods}

\subsection{Study Sites}

The Field trials were conducted both on-station and on-farm in Salima, Lilongwe and Dedza districts located in central region of Malawi. Salima District is located in the lake shore agro-ecological zone which lies between 200 to $700 \mathrm{~m}$ above sea level having semi-arid climate with monthly rainfall range from 0 to $339 \mathrm{~mm}$, and mean monthly minimum and maximum temperatures range from $16^{\circ} \mathrm{C}$ to $22^{\circ} \mathrm{C}$ and $26^{\circ} \mathrm{C}$ to $33^{\circ} \mathrm{C}$. The land is generally flat to gently undulating, with deep Fluvisols in the valleys and the shore lands of Lake Malawi. Lilongwe district is located in the mid-elevation which is between 760 and $1300 \mathrm{~m}$ above sea having a sub humid climate with monthly rainfall range of 1 to $221 \mathrm{~mm}$; and minimum and maximum mean temperatures range of $8^{\circ} \mathrm{C}$ to $17^{\circ} \mathrm{C}$ and $24^{\circ} \mathrm{C}$ to $30^{\circ} \mathrm{C}$, respectively [15]. The zone has predominantly shallow latosols in escarpments; deep well drained latosols in the plateau and poorly drained sand and clay soils in the valleys. Other important soil groups include Ferrasols, Luvisols, Lixisols Lithic and Leptosols [16].

Dedza District is located in the highlands with altitude of greater than $1300 \mathrm{~m}$ above sea level having a sub-humid climate with annual rainfall range of $>1000$ $\mathrm{mm}$ and minimum and maximum mean temperatures range of $9^{\circ} \mathrm{C}$ to $16^{\circ} \mathrm{C}$ and $19^{\circ} \mathrm{C}$ to $25^{\circ} \mathrm{C}$, respectively. The analysed initial data for the physical and chemical properties of the soil for the three study districts are given in Table 1.

\subsection{Treatments and Experimental Designs}

The trials were established both on-station and on-farm for 3 years during 2013 to 2016 crop growing seasons. There were 11 different fertilizer treatments of $\mathrm{P}$ and $\mathrm{K}$ as sole elements or in combination of different rates. For on-station trials treatment combinations in Table 2 were arranged in a randomized complete

Table 1. Soil analytical data for the three trial sites in Malawi.

\begin{tabular}{|c|c|c|c|c|c|c|c|c|c|}
\hline \multirow{2}{*}{ Location } & \multirow{2}{*}{ Texture } & \multirow{2}{*}{$\mathrm{pH}$} & \multirow{2}{*}{$\begin{array}{l}\text { SOC }^{+} \\
\text {g. } \mathrm{kg}^{-1}\end{array}$} & $\mathbf{P}$ & $\mathrm{K}$ & $\mathrm{Mg}$ & $S$ & $\mathrm{Zn}$ & B \\
\hline & & & & \multicolumn{6}{|c|}{$\mathrm{mg} \cdot \mathrm{kg}^{-1}$} \\
\hline Lilongwe & $\mathrm{SC}^{*}$ & 5.64 & 1.53 & 13.31 & 0.29 & 1.15 & 10.08 & 2.73 & 0.13 \\
\hline Dedza & SC & 5.23 & 1.01 & 7.66 & 0.27 & 1.30 & 8.34 & 1.98 & 0.08 \\
\hline Salima & $\mathrm{SCL}^{* *}$ & 6.43 & 0.98 & 10.67 & 0.40 & 2.35 & 9.06 & 1.94 & 0.17 \\
\hline
\end{tabular}

Table 2. Nutrient rates combinations for different fertilizer treatments applied.

\begin{tabular}{cccc}
\hline \multicolumn{4}{c}{ Nutrient Combinations $(\mathrm{kg} / \mathrm{ha})$} \\
\hline $\mathbf{0 K}+\mathbf{P}$ & $\mathbf{2 0 K}+\mathbf{P}$ & $\mathbf{1 5 P}+\mathrm{K}$ & Diagnostic \\
\hline 0 & 0 & 0 & $15 \mathrm{P}, 20 \mathrm{~K}, 15 \mathrm{~S}, 2.5 \mathrm{Zn}, 10 \mathrm{Mg}, 0.5 \mathrm{~B}$ \\
7.5 & 7.5 & 10 & \\
15 & 15 & 20 & \\
22.5 & 22.5 & & \\
\hline
\end{tabular}


block design with three replications. In Table 2, the first column means that only the amounts of $\mathrm{P}$ rates $(\mathrm{kg} / \mathrm{ha})$ were applied alone; the second column means $\mathrm{P}$ rates were applied in combination with $20 \mathrm{~kg} / \mathrm{ha} \mathrm{K}$; third column means that the amount of $\mathrm{K}$ rates were applied in combination with $15 \mathrm{~kg} / \mathrm{ha} P$ while for the last column of diagnostic means $15 \mathrm{~kg} / \mathrm{ha} \mathrm{P}$ was applied in combination with 20 $\mathrm{kg} / \mathrm{ha} \mathrm{K}, 15 \mathrm{~kg} / \mathrm{ha} \mathrm{S}, 2.5 \mathrm{~kg} / \mathrm{ha} \mathrm{Zn,} 10 \mathrm{~kg} / \mathrm{ha} \mathrm{Mg}$ and $0.5 \mathrm{~kg} / \mathrm{ha} \mathrm{B}$.

For the on-farm trials, there were 5 replicates and each farm with all the treatments was regarded as a single replication.

The plots consisted of 6 ridges of each measuring $6 \mathrm{~m}$ long and spaced at 0.6 $\mathrm{m}$. The soybean seeds were planted on the ridges one seed per planting station spaced at $15 \mathrm{~cm}$ apart. All the trial plots were surrounded with 4 border rows to control the external sources of variations. The soybean plants were harvested from a net plot of 4 ridges each $4 \mathrm{~m}$ long.

\subsection{Data Collection}

\subsubsection{Soil Data}

Initial bulk soil samples were collected from the sites before land preparation. Soil samples were taken from 8 points across the field along each of the blocks (replicates). The samples were air dried, sieved using a $2 \mathrm{~mm}$ sieve and analyzed for particle size distribution, $\mathrm{pH}$, organic carbon (OC), total $\mathrm{N}$, exchangeable bases, exchangeable $\mathrm{K}, \mathrm{Ca}, \mathrm{Mg}$ and $\mathrm{Na}$. All soil analyses were done by the soil laboratory ICRAF in Nairobi, Kenya.

\subsubsection{Crop Data}

The soybean grain yield data was collected by harvesting plants from a net plot of two central ridges of five meters long. Then 100 seeds were dried in an oven at $70^{\circ} \mathrm{C}-80^{\circ} \mathrm{C}$ for 24 hours for moisture content determination. In calculating the soybean grain yield the moisture content was adjusted to $12.5^{\circ} \mathrm{C}$. Thereafter, soybean grain yield for each plot was converted to $\mathrm{kg} / \mathrm{ha}$. From the same net plot, the other data collected included total plant biomass per hectare and plant stand count at harvest. The other collected data was the cost of inputs, crop commodity prices, rainfall and etc. The collected data was used to calculate several variables that included: harvest index $(\mathrm{HI})$, changes in yield variables, rain use efficiency (RUE), agronomic efficiency of P (AEP) and K (AEK), economically optimum rates (EOR), value cost ratio (VCR) and economically optimal rates (EOR) were calculated using Microsoft excel. The following were the formulas used: 1 ) $\mathrm{HI}=\mathrm{Y} / \mathrm{B}$ where $\mathrm{Y}$ is the total grain yield per hectare and $\mathrm{B}$ is the total biomass per hectare; 2) AEX $=\mathrm{Y} / \mathrm{N}$ where $\mathrm{AEX}$ is agronomic efficiency of $\mathrm{X}$ and $\mathrm{X}$ is either $\mathrm{K}$ or $\mathrm{P}$; $\mathrm{Y}$ is the total grain yield per hectare and $\mathrm{N}$ is amount of either $\mathrm{P}$ or $\mathrm{K}$ applied per hectare; 3) $\mathrm{RUE}=\mathrm{Y} / \mathrm{R}$ where $\mathrm{Y}$ is the total grain yield per hectare and $\mathrm{R}$ is amount of rain received during the period of crop production [17].

\subsection{Statistical Analysis}

Analysis of variance (ANOVA) was used to determine variation in yield due to 
different levels of PK by site-year and combinations. The effect of P and K fertilizer and their interactions were the primary focus of the analysis. The changes or differences in yield variables were considered significant when $\mathrm{P} \leq 0.05$. Post-hoc comparisons of means were done using Dunnett's test at $\mathrm{P}$ value $=$ 0.05 .

When significant effects of $\mathrm{P}$ rate by $\mathrm{K}$ rate did not occur, asymptotic regression was fitted to the yield data in order to determine response to $\mathrm{N}$. The asymptotic function is given as yield $\left(\mathrm{Mg} \cdot \mathrm{ha}^{-1}\right) \mathrm{y}=\mathrm{a}-\mathrm{bc}$, where a is soybean yield at the plateau (i.e. expected maximum), b is the amplitude (the gain in soybean yield for applied nutrients), c is a curvature coefficient and $N$ is the nutrient rate applied. The regression analyses for $\mathrm{N}$ rate effects included treatments with and without $P$ separately. Then EORs were calculated using the OFRA fertilizer optimization tool developed by University of Nebraska, Lincoln in USA.

Rain use efficiency (RUE) which is the ratio of grain yield to seasonal total rainfall was calculated and used as proxy for water use efficiency (WUE). RUE has been suggested as a robust indicator of determining the crop productivity and land degradation in areas with limited moistures [18]. Therefore, RUE was used in this study as a metric for evaluating WUE.

Nutrient use efficiency by the soybean crop was assessed focusing on the agronomic efficiency of $\mathrm{P}$ (AEP) at fixed $\mathrm{K}$ rates and agronomic efficiency of $\mathrm{K}$ (AEK) at fixed P levels. AEP was calculated as a ratio of the increased crop output to the amount of $P$ applied. AEK was calculated in the same manner as AEP.

Returns to fertilizer use were assessed using the value-cost ratio (VCR) because it is commonly used when evaluating the profitability of fertilizer use, especially when there unavailable data on full production costs. Hence, VCR was calculated as a ratio of value of increased crop output to the cost of fertilizer applied. A VCR $\geq 2$ means a $100 \%$ return on the use of money spent in buying fertilizer and is adequate to guarantee investing in fertilizer [19]. Therefore, in this analysis VCR $\geq 2$ was considered as a reasonable critical value for assessing the risk associated with use of fertilizers at the small scale of smallholder farms.

All analyses were done using the Statistix 10 (Analytical Software. Tallahassee).

\section{Results and Discussion}

\subsection{Soybean Grain Yield and Harvest Index}

Soybean grain yield responses to different fertilizer rates at different sites are given in Table 3 . The results show that there were significant soybean grain yield responses to fertilizer rates in the three sites (at Salima, $\mathrm{P}=0.000$; Dedza, $\mathrm{P}=$ 0.0098 , and Lilongwe, $P=0.0068)$. The lowest soybean grain yield $(<1352 \mathrm{~kg} / \mathrm{ha})$ response was obtained in the control in all the three districts. The highest soybean grain yield obtained was $1790 \mathrm{~kg} / \mathrm{ha}, 1708 \mathrm{~kg} / \mathrm{ha}$ and $1921 \mathrm{~kg} / \mathrm{ha}$ at Salima, Dedza and Lilongwe respectively when a rate of $20 \mathrm{~kg} / \mathrm{ha} \mathrm{P}$ plus $22.5 \mathrm{~kg} / \mathrm{ha} \mathrm{K}$ 
Table 3. Soybean grain yield and change in grain yield relative to the control (Change) due to application of different fertilizer rates at Salima, Dedza and Lilongwe.

\begin{tabular}{ccccccc}
\hline & \multicolumn{5}{c}{ Soybean Grain Yield (kg/ha) } \\
\cline { 2 - 7 } Amount nutrient & \multicolumn{2}{c}{ Salima } & \multicolumn{2}{c}{ Dedza } & \multicolumn{2}{c}{ Lilongwe } \\
\cline { 2 - 7 } & Mean & Change & Mean & Change & Mean & Change \\
\cline { 2 - 7 } 0K, 0P & 1139.1 & & 1102.5 & 1351.9 & \\
0K, 7.5P & 1598.9 & $459.8^{*}$ & 1626.5 & $524.0^{*}$ & 1726.4 & $74.6^{*}$ \\
0K, 15P & 1723.4 & $584.3^{*}$ & 1548.8 & $446.3^{*}$ & 1760 & $08.1^{*}$ \\
0K, 22.5P & 1786.4 & $647.3^{*}$ & 1588.6 & $486.1^{*}$ & 1759.1 & $07.3^{*}$ \\
20k, 0p & 1458.7 & 319.6 & 1359.6 & 257.1 & 1540.8 & 189 \\
20k, 7.5p & 1498.6 & $359.5^{*}$ & 1643.7 & $541.3^{*}$ & 1775.2 & $23.4^{*}$ \\
20k, 15p & 1703.8 & $564.8^{*}$ & 1365.7 & 263.2 & 1818.4 & $66.6^{*}$ \\
20k, 22.5p & 1789.9 & $650.9^{*}$ & 1708.0 & $605.5^{*}$ & 1921 & $69.2^{*}$ \\
15P, 10K & 1635.1 & $496.0^{*}$ & 1481.6 & 379.1 & 1850.2 & $98.3^{*}$ \\
15P, 30K & 1555.7 & $416.6^{*}$ & 1575.1 & $472.6^{*}$ & 1704.2 & 352.3 \\
Diagnostic & 1593.8 & $454.7^{*}$ & 1478.1 & 375.6 & 1698.7 & 346.8 \\
CV (\%) & 17.28 & & 21.40 & & 19.30 & \\
P (0.05) & 0.00 & & 0.01 & & 0.01 & \\
Critical D Value & 2.77 & & 2.78 & & 2.76 & \\
\hline
\end{tabular}

Diagnostic: This consists of $15 \mathrm{p}, 20 \mathrm{~K}, 15 \mathrm{~S}, 2.5 \mathrm{Zn}, 10 \mathrm{Mg}, 0.5 \mathrm{~B}$. Values of Change followed by * show that there were significant mean yield differences among the treatments and changes from the control according to Dunnett's test.

was applied with the yield difference of $651 \mathrm{~kg} / \mathrm{ha}, 606 \mathrm{~kg} / \mathrm{ha}$ and $491 \mathrm{~kg} / \mathrm{ha}$ respectively. This means the rate of gave the optimum soybean grain yield response to applied fertilizers. The results are similar to what other researchers found in Uganda where the amount of $15 \mathrm{~kg} / \mathrm{ha} \mathrm{P}$ and $20 \mathrm{~kg} / \mathrm{ha} \mathrm{K}$ gave high increase in soybean yield [10] while in Nigeria only application of $\mathrm{P}$ contributed towards yield increase and not $\mathrm{K}$ [12]. The response of soybean to $\mathrm{P}$ application was due to low soil levels of $\mathrm{P}$ (Table 1) while the non-response to $\mathrm{K}$ in Dedza was due to low $\mathrm{pH}$ of the soil (Table 1).

The results on the soybean harvest index for the three districts are given in Table 4. Harvest index did not significantly differ with treatment except on in Dedza district $(\mathrm{P}=0.0014)$. Although not statistically significant there was an increase in harvest index with $\mathrm{P}$ and $\mathrm{K}$ application relative to the control. The highest harvest index increase was about $25 \%$ for fertilizer treatment of $20 \mathrm{~kg} / \mathrm{ha}$ $\mathrm{P}$ plus $22.5 \mathrm{~kg} / \mathrm{ha} \mathrm{K}$ in Dedza, about $16 \%$ for fertilizer rate of $22.5 \mathrm{~kg} / \mathrm{ha} \mathrm{P}$ in Salima and about $10 \%$ for the rate of $15 \mathrm{~kg} / \mathrm{ha} \mathrm{P}$ plus $10 \mathrm{~kg} / \mathrm{ha} \mathrm{K}$ in Lilongwe districts. The increase in harvest index with increase in fertilizer addition indicates that the applied nutrient positively affected soybean yield production. 
Table 4. Variation in harvest index and change relative to the control (Change) due to application of fertilizers.

\begin{tabular}{|c|c|c|c|c|c|c|}
\hline \multirow{3}{*}{$\begin{array}{l}\text { Amount nutrient Applied } \\
\qquad(\mathrm{kg} / \mathrm{ha})\end{array}$} & \multicolumn{6}{|c|}{ Harvest Index } \\
\hline & \multicolumn{2}{|c|}{ Salima } & \multicolumn{2}{|c|}{ Dedza } & \multicolumn{2}{|c|}{ Lilongwe } \\
\hline & Mean & Change & Mean & Change & Mean & Change \\
\hline $0 \mathrm{~K}, \mathrm{OP}$ & 0.39 & & 0.35 & & 0.41 & \\
\hline $0 \mathrm{~K}, 7.5 \mathrm{P}$ & 0.44 & 0.04 & 0.47 & $0.12^{\star}$ & 0.44 & 0.03 \\
\hline $0 \mathrm{~K}, 15 \mathrm{P}$ & 0.44 & 0.04 & 0.45 & $0.10^{*}$ & 0.44 & 0.03 \\
\hline $0 \mathrm{~K}, 22.5 \mathrm{P}$ & 0.46 & $0.06^{*}$ & 0.42 & 0.07 & 0.43 & 0.02 \\
\hline $20 \mathrm{k}, 0 \mathrm{p}$ & 0.42 & 0.02 & 0.42 & 0.07 & 0.44 & 0.03 \\
\hline $20 \mathrm{k}, 7.5 \mathrm{p}$ & 0.43 & 0.03 & 0.44 & $0.10^{*}$ & 0.43 & 0.02 \\
\hline $20 \mathrm{k}, 15 \mathrm{p}$ & 0.42 & 0.03 & 0.46 & $0.10^{\star}$ & 0.43 & 0.02 \\
\hline $20 \mathrm{k}, 22.5 \mathrm{p}$ & 0.44 & 0.05 & 0.47 & $0.12^{\star}$ & 0.40 & -0.02 \\
\hline $15 \mathrm{P}, 10 \mathrm{~K}$ & 0.44 & 0.04 & 0.47 & $0.12^{\star}$ & 0.45 & 0.04 \\
\hline $15 \mathrm{P}, 30 \mathrm{~K}$ & 0.43 & 0.03 & 0.44 & $0.09^{*}$ & 0.40 & -0.01 \\
\hline Diagnostic & 0.42 & 0.03 & 0.44 & $0.09^{*}$ & 0.40 & -0.01 \\
\hline CV (\%) & 12.08 & & 12.77 & & 12.13 & \\
\hline $\mathrm{P}(0.05)$ & 0.38 & & 0.00 & & 0.08 & \\
\hline Critical D Value & 2.77 & & 2.78 & & 2.76 & \\
\hline
\end{tabular}

Values of Change followed by ${ }^{*}$ show that there were significant mean yield differences among the treatments and changes from the control according to Dunnett's test.

\subsection{Rain Use Efficiency by Soybean}

Rain use efficiency (RUE) results as affected by responses of soybean to different nutrient rate applications are given in Table 5. The results indicate that there were significant differences in RUE with application of different nutrient rates in all the three districts. There was an increase in RUE by soybean crops with an increase in nutrient application among the treatments as compared with the control in all the three sites. The highest values of RUE obtained in the P rate of $22.5 \mathrm{~kg} / \mathrm{ha}$, and $20 \mathrm{~kg} / \mathrm{ha} \mathrm{P}$ plus $22.5 \mathrm{~kg} / \mathrm{ha} \mathrm{K}$ in Salima, $15 \mathrm{~kg} \mathrm{P} / \mathrm{ha}$ plus $10 \mathrm{~kg} / \mathrm{ha}$ $\mathrm{K}$ in Dedza and $20 \mathrm{~kg} / \mathrm{ha} \mathrm{P}$ plus $22.5 \mathrm{~kg} / \mathrm{ha} \mathrm{K}$ in Lilongwe. This represents a $54 \%$, $34 \%$ and $42 \%$ increase over the control in Salima, Dedza and Lilongwe, respectively. The increase in RUE was due to enhanced metabolic activities by the supplied nutrients to the soybean crop.

\subsection{Agronomic Use Efficiency of Phosphorous and Potassium in Soybean}

Results of agronomic use efficiency of $\mathrm{P}$ (AEP) in soybean grain yield production in given in Table 6. In general, the results show significant soybean grain yield differences at $\mathrm{P}=0.05$ in all the three agro-ecological zones. In all the sites, the highest AEP values were obtained when the amount of applied P was 7.5 $\mathrm{kg} / \mathrm{ha}$. The PUS values were $213 \mathrm{~kg}$ grain $/ \mathrm{kg}$ P, $216.86 \mathrm{~kg}$ grain $/ \mathrm{kg} \mathrm{P}$ and $57.84 \mathrm{~kg}$ 
Table 5. Effect of nutrient application to soybean crop on rain use efficiency (RUE) and change in RUE relative to the control (Change).

\begin{tabular}{|c|c|c|c|c|c|c|}
\hline \multirow{3}{*}{$\begin{array}{l}\text { Amount nutrient Applied } \\
\qquad(\mathrm{kg} / \mathrm{ha})\end{array}$} & \multicolumn{6}{|c|}{ Rainwater Use Efficiency ( $\mathrm{kg}$ grain $/ \mathrm{mL}$ of rain water) } \\
\hline & \multicolumn{2}{|c|}{ Salima } & \multicolumn{2}{|c|}{ Dedza } & \multicolumn{2}{|c|}{ Lilongwe } \\
\hline & Mean & Change & Mean & Change & Mean & Change \\
\hline $0 \mathrm{~K}, 0 \mathrm{P}$ & 1.50 & & 1.44 & & 1.76 & \\
\hline $0 \mathrm{~K}, 7.5 \mathrm{P}$ & 2.10 & $0.60^{*}$ & 2.12 & $0.68^{\star}$ & 2.25 & $0.49^{\star}$ \\
\hline $0 \mathrm{~K}, 15 \mathrm{P}$ & 2.20 & $0.80^{*}$ & 2.02 & $0.58^{\star}$ & 2.29 & $0.53^{*}$ \\
\hline $0 \mathrm{~K}, 22.5 \mathrm{P}$ & 2.30 & $0.84^{*}$ & 2.07 & $0.63^{*}$ & 2.29 & $0.53^{*}$ \\
\hline $20 \mathrm{k}, 0 \mathrm{p}$ & 1.90 & 0.42 & 1.77 & 0.33 & 2.01 & 0.24 \\
\hline $20 \mathrm{k}, 7.5 \mathrm{p}$ & 1.95 & $0.47^{\star}$ & 2.14 & $0.71^{\star}$ & 2.31 & $0.55^{\star}$ \\
\hline $20 \mathrm{k}, 15 \mathrm{p}$ & 2.22 & $0.74^{*}$ & 1.78 & 0.34 & 2.37 & $0.61^{*}$ \\
\hline $20 \mathrm{k}, 22.5 \mathrm{p}$ & 2.33 & $0.84^{*}$ & 2.23 & $0.79^{*}$ & 2.50 & $0.74^{\star}$ \\
\hline $15 \mathrm{P}, 10 \mathrm{~K}$ & 2.13 & $0.64^{*}$ & 1.93 & 0.49 & 2.41 & $0.64^{*}$ \\
\hline $15 \mathrm{P}, 30 \mathrm{~K}$ & 2.02 & $0.54^{*}$ & 2.05 & $0.62^{\star}$ & 2.22 & 0.46 \\
\hline Dianostic & 2.08 & $0.59^{*}$ & 1.93 & 0.49 & 2.21 & 0.45 \\
\hline CV (\%) & 17.28 & & 21.40 & & 19.3 & \\
\hline $\mathrm{P}(0.05)$ & 0.00 & & 0.01 & & 0.01 & \\
\hline Critical D Value & 2.77 & & 2.78 & & 2.76 & \\
\hline
\end{tabular}

Values of Change followed by *show that there were significant mean yield differences among the treatments and changes from the control according to Dunnett's test.

Table 6. Agronomic use efficiency of phosphorous (AEP) and changes in AEP relative to the control (Change) in soybean.

\begin{tabular}{ccccccc}
\hline & \multicolumn{3}{c}{ Agronomic Use Efficiency of Phosphorous (kg grain/kg P) } \\
\cline { 2 - 7 } Applied P (kg/ha) & \multicolumn{2}{c}{ Salima } & \multicolumn{2}{c}{ Dedza } & \multicolumn{2}{c}{ Lilongwe } \\
\cline { 2 - 7 } & Mean & Change & Mean & Change & Mean & Change \\
\hline 7.5 & 213.18 & & 216.86 & 57.84 & \\
15 & 133.01 & $-80.17^{*}$ & 103.25 & $-113.61^{*}$ & 32.91 & $-24.93^{*}$ \\
22.5 & 79.39 & $-133.79^{*}$ & 70.6 & $-146.26^{*}$ & 21.52 & $-36.33^{*}$ \\
CV (\%) & 21.11 & & 24.63 & & 66.17 & \\
P (0.05) & 0.00 & & 0.00 & & 0.01 & \\
Critical D Value & 2.38 & & 2.42 & 2.36 & \\
\hline
\end{tabular}

Values of Change followed by * show that there were significant mean yield differences among the treatments and changes from the control according to Dunnett's test.

grain/kg P in Salima, Dedza and Lilongwe respectively. However, with increasing amount of P rate from $7.5 \mathrm{~kg} / \mathrm{ha}$ to $22.5 \mathrm{~kg} \mathrm{P} / \mathrm{ha}$, the AEP started to decrease at all sites as indicated by the negative soybean yield differences (Table 4).

The results of agronomic use efficiency of potassium (AEK) in soybean grain yield production are given in Table 7 for the three agro-ecological zones. There were significant $(\mathrm{P}=0.05)$ differences in AEK in all the three districts except for 
Table 7. Agronomic use efficiency of potassium (AEK) and changes in AEK relative to the control (Change) in soybean.

\begin{tabular}{ccccccc}
\hline \multirow{2}{*}{$\begin{array}{c}\text { Amount of applied K } \\
(\mathrm{kg} / \mathrm{ha})\end{array}$} & \multicolumn{3}{c}{ Agronomic Use Efficiency of Potassium $(\mathrm{kg}$ grain/kg K) } \\
\cline { 2 - 7 } & \multicolumn{2}{c}{ Salima } & \multicolumn{2}{c}{ Dedza } & \multicolumn{2}{c}{ Lilongwe } \\
\cline { 2 - 7 } & Mean & Change & Mean & Change & Mean & Change \\
\hline 10 & 109.01 & & 98.77 & & 13.83 & \\
20 & 79.69 & $-29.32^{*}$ & 73.90 & $-24.87^{*}$ & 14.26 & 0.42 \\
30 & 51.86 & $-57.15^{*}$ & 52.50 & $-46.27^{*}$ & 9.59 & -4.24 \\
CV (\%) & 25.41 & & 21.57 & & 61.46 & \\
P (0.05) & 0.00 & & 0.00 & & 0.28 & \\
Critical D Value & 2.38 & & 2.42 & & 2.36 & \\
\hline
\end{tabular}

Values of Change followed by ${ }^{*}$ show that there were significant mean yield differences among the treatments and changes from the control according to Dunnett's test.

Lilongwe. The AEK decreased with an increased in the amount of $\mathrm{K}$ rates applied. The highest AEK was obtained in Salima and Dedza districts when the rate of applied $\mathrm{K}$ was $10 \mathrm{~kg} / \mathrm{ha}$ and in Lilongwe when the rate of applied $\mathrm{K}$ was 20 $\mathrm{kg} / \mathrm{ha}$. However, the AEK values at optimum rates were 10 times higher in Salima and Dedza than those of Lilongwe. The differences could be ascribed to the variations in climatic and soil factors among the three agro-ecological zones. Although the highest AEK in Lilongwe was obtained when $20 \mathrm{~kg} \mathrm{~K} / \mathrm{ha}$ were applied, the increase in AEK was almost the same with the one obtained when 10 $\mathrm{kg} \mathrm{K} /$ ha was applied in Lilongwe.

\subsection{Return to Fertilizer Use}

The results on profit returns to fertilizer use are given in Table 8. Profit returns to fertilizer use significantly differed with treatments in all the three districts. The highest VCR of 10.79, 10.61, and 11.46 were obtained in Dedza, Salima and Lilongwe respectively when the amount of applied P was $7.5 \mathrm{~kg} / \mathrm{ha}$. While the second highest VCR values of 8.97, 9.62 and 10.16 in Dedza, Salima and Lilongwe Districts respectively were obtained when $20 \mathrm{~kg} / \mathrm{ha} \mathrm{K}$ was applied in each district. The lowest VCR values of 2.97 and 3.28 were obtained in Dedza and Lilongwe respectively when the nutrients rate of $20 \mathrm{~kg} / \mathrm{ha} \mathrm{K}$ plus $22.5 \mathrm{~kg} / \mathrm{ha} P$ were applied while in Salima the lowest VCR value of 2.94 was obtained when the nutrient rate of $15 \mathrm{~kg} / \mathrm{ha} \mathrm{P}$ plus $30 \mathrm{~kg} / \mathrm{ha} \mathrm{K}$ was applied. The results imply that the most economical and profitable rate was $7.5 \mathrm{~kg} / \mathrm{ha} \mathrm{P}$ in all the three districts and while the lowest economical and profitable VCR value was obtained when 20 $\mathrm{kg} / \mathrm{ha} \mathrm{K}$ plus $22.5 \mathrm{~kg} / \mathrm{ha} \mathrm{P}$ of nutrient rate was applied in Dedza and Lilongwe and $15 \mathrm{~kg} / \mathrm{ha} \mathrm{P}$ plus $30 \mathrm{~kg} / \mathrm{ha} \mathrm{K}$ was applied in Salima. All the VCR values obtained by different use of nutrient rates were above two implying that all the applied fertilizer rates had a reasonable threshold for covering the risk associated with using fertilizer among financially constrained smallholder farmers. These results suggest that different nutrients in different combinations influence indi- 
Table 8. Value cost ratio (VCR) for soybean grain yields.

\begin{tabular}{ccccccc}
\hline \multirow{2}{*}{ Treatment } & \multicolumn{5}{c}{ Value cost ratio (VCR) for soybean } \\
\cline { 2 - 7 } & \multicolumn{2}{c}{ Salima } & \multicolumn{2}{c}{ Dedza } & \multicolumn{2}{c}{ Lilongwe } \\
\cline { 2 - 7 } Mean & Change & Mean & Change & Mean & Change \\
\hline 0K, 7.5p & 10.61 & & 10.79 & & 11.46 & \\
0K, 15P & 5.72 & $-4.89^{*}$ & 5.14 & $-5.66^{*}$ & 5.84 & $-5.62^{*}$ \\
0K, 22.5P & 3.95 & $-6.66^{*}$ & 3.52 & $-7.28^{*}$ & 3.89 & $-7.57^{*}$ \\
20k, 0p & 9.62 & -0.99 & 8.97 & $-1.83^{*}$ & 10.16 & -1.30 \\
20k, 7.5p & 4.96 & $-5.66^{*}$ & 5.44 & $-5.36^{*}$ & 5.87 & $-5.59^{*}$ \\
20k, 15p & 3.76 & $-6.85^{*}$ & 3.02 & $-7.78^{*}$ & 4.01 & $-7.44^{*}$ \\
20k, 22.5p & 2.97 & $-7.64^{*}$ & 2.83 & $-7.96^{*}$ & 3.18 & $-8.28^{*}$ \\
$15 \mathrm{P}, 10 \mathrm{~K}$ & 4.34 & $-6.28^{*}$ & 3.93 & $-6.87^{*}$ & 4.93 & $-6.53^{*}$ \\
$15 \mathrm{P}, 30 \mathrm{~K}$ & 2.94 & $-7.67^{*}$ & 2.98 & $-7.82^{*}$ & 3.22 & $-8.24^{*}$ \\
$15 \mathrm{p}, 20 \mathrm{~K}, 15 \mathrm{~S}, 2.5 \mathrm{Zn}$, & 3.52 & $-7.09^{*}$ & 3.26 & $-7.53^{*}$ & 3.75 & $-7.71^{*}$ \\
CV (\%) & 19.52 & & 27.59 & & 25.06 & \\
P (0.05) & 0.000 & & 0.000 & & 0.000 & \\
Critical D Value & 2.74 & & 2.76 & & 2.74 & \\
\hline
\end{tabular}

Values of Change followed by ${ }^{*}$ show that there were significant mean yield differences among the treatments and changes from the control according to Dunnett's test.

vidually or both with other nutrients on the most economical and profitable nutrient rates that a farmer can choose to apply.

\subsection{Economically Optimum Fertilizer Rates for Soybean in Three Agro-Ecological Zones}

Table 9 gives the results of the soybean grain yield responses to $\mathrm{P}$ and $\mathrm{K} \mathrm{nu}$ trients, $\mathrm{a}, \mathrm{b}$, and $\mathrm{c}$ coefficients of the soybean grain to plateau response curve, increase in soybean grain yield associated with increased changes in applied rates of nutrient (column 6 - 9), EOR was calculated from the results of field trials (column 10 and 11) and the already recommended application rates of nutrient. The results indicate that soybean responded well to $\mathrm{P}$ and it was profitable in all the agro-ecological zones tested. There was economical responses of soybean to $\mathrm{K}$ application in all the agro-ecological zones except for highlands $(>1300 \mathrm{~m})$. The response of soybean grain yield to $\mathrm{K}$ application was reported in Uganda [10] and Kenya [20]. In case of the non response of soybean yield to $\mathrm{K}$ application was also reported in Nigeria which did not contribute towards increase in soybean grain yield [7]. The EOR for P were similar to the recommended rates for soybean however, for $\mathrm{K}$ they were not similar for all agro-ecological zones except for highland agro-ecological zone where they were same. The soybean EOR recommendations was slightly higher than the recommended in highlands and within the recommended rates in mid and low agro-ecological zones. 
Table 9. Curves of response, expected increase in yields ( $t / h a)$ for nutrients, and OFRA economically optimal rate (EOR) in maximizing profit per unit area comparing with recent (REC) recommendations $\mathrm{P}_{2} \mathrm{O}_{5}=\mathrm{P} \times 2.29 ; \mathrm{K}_{2} \mathrm{O}=\mathrm{K} \times 1.2$. The response in some functions was zero for lacking response or information.

\begin{tabular}{|c|c|c|c|c|c|c|c|c|c|c|}
\hline \multirow{3}{*}{$\begin{array}{l}\text { Site and } \\
\text { altitude } \\
\text { in } \mathrm{m}\end{array}$} & \multicolumn{4}{|c|}{$\begin{array}{c}\text { Response coefficients, } \\
\text { Yield }=\mathrm{a}-\mathrm{bc} \mathrm{c}^{\mathrm{r}} \\
\mathrm{r}=\text { elemental nutrient rate }\end{array}$} & \multicolumn{4}{|c|}{$\begin{array}{l}\text { Increase in yield due to } \\
\text { incremental increase in } \\
\text { elemental nutrient rate }(\mathrm{kg} / \mathrm{ha})\end{array}$} & \multicolumn{2}{|c|}{$\begin{array}{l}\text { Recommended } \\
\text { nutrient rate }\end{array}$} \\
\hline & & $\mathrm{a}$ & $\mathrm{b}$ & c & $0-5$ & $5-10$ & $10-15$ & $15-20$ & $\mathrm{EOR}^{\dagger}$ & $\operatorname{Rec}^{\dagger \dagger}$ \\
\hline & \multicolumn{4}{|c|}{ Nutrient $\mathrm{t} / \mathrm{ha}$} & \multicolumn{4}{|c|}{ Yield increase, $\mathrm{kg} / \mathrm{ha}$} & \multicolumn{2}{|c|}{$\mathrm{kg} / \mathrm{ha}$} \\
\hline Dedza & $\mathrm{P}$ & 1.457 & 0.607 & 0.883 & 0.281 & 0.151 & 0.081 & 0.043 & 20 & $9-18$ \\
\hline$(>1300)$ & K & 0.837 & 0.019 & 0.908 & 0.007 & 0.004 & 0.003 & 0.002 & 0 & 0 \\
\hline Lilongwe & $\mathrm{P}$ & 1.359 & 0.608 & 0.868 & 0.308 & 0.152 & 0.075 & 0.037 & 17 & $9-18$ \\
\hline$(760-1300)$ & K & 1.402 & 0.508 & 0.781 & 0.360 & 0.105 & 0.030 & 0.009 & 16 & 0 \\
\hline Salima & $\mathrm{P}$ & 1.359 & 0.608 & 0.868 & 0.308 & 0.152 & 0.075 & 0.037 & 17 & $9-18$ \\
\hline$(200-760)$ & K & 1.402 & 0.508 & 0.781 & 0.360 & 0.105 & 0.030 & 0.009 & 16 & 0 \\
\hline
\end{tabular}

${ }^{\dagger \dagger}[12] .{ }^{\dagger} \mathrm{EOR}$ was calculated based on the buying price of MK 23,000 for $50 \mathrm{~kg}$ NPS fertilizer and MK 25,000 for $50 \mathrm{~kg} \mathrm{KCl}$ and TSP. The selling price of MK 350/kg grain soybean.

Soybean responses to applied $\mathrm{P}$ and $\mathrm{K}$ at different sites and across different seasons followed a typical curvilinear to plateau in Salima, Dedza and Lilongwe districts. There was a steep increase in soybean grain yield with an increase in low rates of applied $\mathrm{P}$ and $\mathrm{K}$, followed by a lower rate of increase at higher rates of applied $\mathrm{P}$ and $\mathrm{K}$, until reaching a plateau in the curve. The results indicate that for the financially able farmers they would usually want to continue applying nutrient until to the point where the value of incremental soybean grain yield is becoming the same with the cost of adding incremental rate of nutrient. While for the financially constrained or limited smallholder farmers, they should try to apply nutrient rates in region where there is still increase in grain yield of soybean.

\subsection{Net Returns with Relation to Applied Monitory Nutrient Value}

The results of net returns with regard to the amount of money spent on the applied nutrients are given in Figure 1. The results generally show that the amount of net returns increases with increase in amount of money spent on fertilizer nutrients applied and then reaches a point where it decreases with increased amount of money spent on nutrient inputs. It is also worthy to note that for financially constrained farmers can take advantage of this range to gain high profit from using nutrients. In the figure, the steeper the slope of the curve indicates the higher the net profit gained on investing in nutrient use. This means that when the amount of money invested on nutrients increases, the slope decreases until it reaches a peak and the slope becomes flat, and the reached point of maximizing profit per unit area. As the slope of the curve decline, it means the profit is also declining. In this case the financially constrained farmer should 


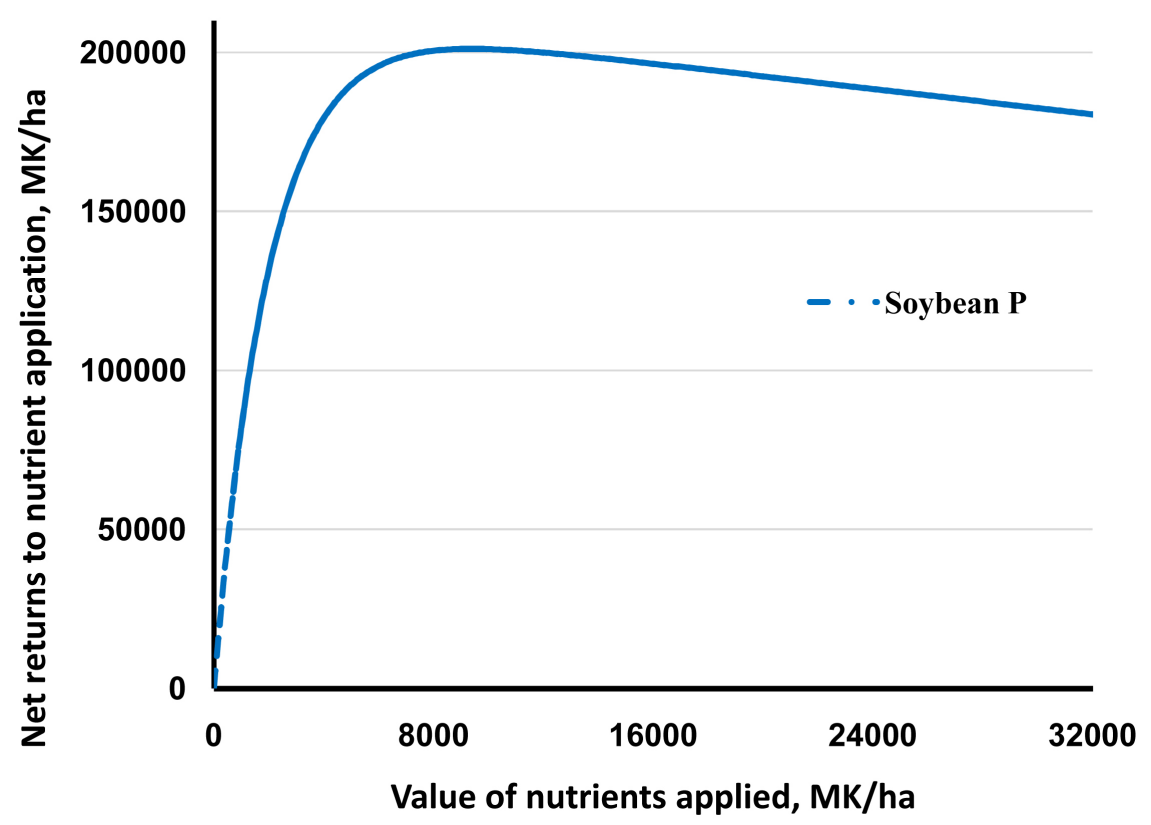

Figure 1. The net returns of investing in nutrient use in soybean for Highlands AEZ in Malawi (>1300 masl). The buying price of $50 \mathrm{~kg}$ NPS fertilizer was MK 23,000 and MK 25,000 for $\mathrm{KCl}$ and TSP. The selling price for soybean was MK 350/kg grain.

consider first using the nutrient combination that will be giving the most profit. The trend of these results is similar to what was reported in Uganda [10], Tanzania [21], Kenya [20] and Malawi [22]. Therefore, Kaizzi and his colleagues [10] are suggesting that the farmers who do not have adequate financial resources should be taking advantage of the available chances of profits depending on their affordability. Then hopefully in return they can allocate some of the gained profits to more fertilizer use and slowly move from being constrained financially and eventually apply adequate optimum nutrients rates to all soybean land for maximum profit gain per unit area [5].

\section{Conclusion}

The PK fertilizer rates including diagnostic significantly improved soybean grain yield production, net value of returns, harvest index, rainwater use efficiency and cost value ratio. The VCR values that were the most economical and profitable were for the fertilizer rate of $7.5 \mathrm{~kg} / \mathrm{ha} \mathrm{P}$ in Salima, Dedza and Lilongwe while the lowest economical and profitable NP fertilizer rate was $20 \mathrm{~kg} / \mathrm{ha} \mathrm{K}$ plus $22.5 \mathrm{~kg} / \mathrm{ha} \mathrm{P}$ for Dedza and Lilongwe and $15 \mathrm{~kg} / \mathrm{ha} \mathrm{P}$ plus $30 \mathrm{~kg} / \mathrm{ha} \mathrm{K}$ for Salima District. All the VCR values obtained from applying different PK fertilizer nutrient rates were above two implying that all the applied fertilizer rates had a good value of returns to cover against any risks associated in using fertilizers at smallholder farms. The results also presented different available PK fertilizer application rate options for maximizing profit returns for the financially constrained smallholder farmers. 


\section{Acknowledgements}

We thank AGRA for funding of the OFRA project from which this research data was generated. We also thank CABI for their support of write-shop to finalize this manuscript. We also thank Prof. Charles Wortmann for his valuable comments during the implementation of the field trials.

\section{References}

[1] Franke, A.C., Branda, van den G.J. and Giller, K.E. (2014) Which Farmers Benefit Most from Sustainable Intensification? An Ex-Ante Impact Assessment of Expanding Grain Legume Production in Malawi. European Journal of Agronomy, 58, 28-38. https://doi.org/10.1016/j.eja.2014.04.002

[2] Sinclair, T.R. and Vadez, V. (2012) The Future of Grain Legumes in Cropping Systems. Crop Pasture, 63, 501-512. https://doi.org/10.1071/CP12128

[3] Sinclair, T.R., Marrou, H., Soltani, A., Vadez, V. and Chandolu, K.C. (2014) Soybean Production Potential in Africa. Global Food Security, 3, 31-40. https://doi.org/10.1016/j.gfs.2013.12.001

[4] Kabambe, V., Katunga, L., Kapewa, T. and Ngwira, A.R. (2008) Screening Legumes for Integrated Management of Witchweeds (Alectravogelii and Strigaasiatica) in Malawi. African Journal of Agricultural Research, 3, 708-715.

[5] Kaizzi, K.C., Mohammed, B.M. and Maman, N. (2017) Fertilizer Use Optimization: Principles and Approach. In: Wortmann, C.S. and Keith, S., Eds., Fertilizer Use Optimization in Sub-Saharan Africa, CABI, Nairobi, 9-17.

[6] Munthali M.W. (2007) Integrated Soil Fertility Management Technologies: A Counteract to Existing Milestone in Obtaining Achievable Economical Crop Yields in Cultivated Lands of Poor Smallholder Farmers in Malawi. In: Bationo, A., Waswa, B., Kihara J. and Kimetu, J., Eds., Advances in Integrated Soil Fertility Management in sub-Saharan Africa: Challenges and Opportunities, Springer, Dordrecht, 531-536. https://doi.org/10.1007/978-1-4020-5760-1_50

[7] Tarfa, B.D., Maman, N., Ouattara, K. and Wortmann, C. (2017) Groundnut and Soybean Response to Nutrient Application in West Africa. Agronomy Journal. https://doi.org/10.2134/agronj2017.03.0132

[8] Musiyiwa, K., Mpeperekia, S. and Giller, K.E. (2005) Symbiotic Effectiveness and Host Ranges of Indigenous Rhizobia Nodulating Promiscuous Soybean Varieties in Zimbabwean Soils. Soil Biology and Biochemistry, 37, 1169-1176. https://doi.org/10.1016/j.soilbio.2004.12.004

[9] Wortmann, C.S., Shapiro, C.A., Ferguson, R. and Mainz, M. (2012) Irrigated Soybean Has a Small Response to Nitrogen Applied during Early Reproductive Growth. Crop Management. http://www.plantmanagementnetwork.org/sub/cm/research/2012/nitrogen/

[10] Giller, K.E. and Dashiell, K.E. (2006) Glycine max (L.) Merr. In: Brink, M. and Belay, G., Eds., Plant Resources of Tropical Africa 1. Cereals and Pulses, PROTA Foundation, Wageningen, Netherlands/Backhuys Publishers, Leiden, Netherlands/ CTA, Wageningen, the Netherlands, 76-82.

[11] Kaizzi, K.C., Byalebeka, J., Semalulu, O., Alou, I.N., Zimwanguyizza, W., Nansamba, A., Odama, E., Musinguzi, P., Ebanyat, P., Hyuda, T., Appollo, K., Kasharu, A.K. and Wortmann, C.S. (2012) Optimizing Smallholder Returns to Fertilizer Use: Bean, Soybean and Ground Nut. Field Crops Research, 127, 109-119. 
[12] Chiezey, U.F. (2013) Field Performance of Soybean (Glycine max (L) Merill) with Farmyard Manure and Inorganic P Fertilizers in the Sub-Humid Savanna of Nigeria. Journal of Agricultural Science, 5, 10. https://doi.org/10.5539/jas.v5n10p46

[13] Kumaga, F.K. and Ofori, K. (2004) Response of Soybean to Bradirhizobia Inoculation and Phosphorus Application. International Journal of Agriculture and Biology, 6, 324-327.

[14] Kanyama-Phiri, G.Y., Snapp, S.S., Kamanga, B., and Wellard, K. (2000) Towards Integrated Soil Fertility Management in Malawi: Incorporating Participatory Approaches in Agricultural Research. Managing Africa's Soils No. 11. IIED, UK. http://www.iied.org/drylands

[15] Peel, M.C., Finlayson, B.L. and Mcmahon, T.A. (2007) Updated World Map of the Koppen-Geiger Climate Classification. Hydrology and Earth System Sciences, 11, 1633-1644. https://doi.org/10.5194/hess-11-1633-2007

[16] Jones, A., Breuning-Madsen, H., Brossard, M., Dampha, A., Deckers, J., Dewitte, O., Hallett, S., Jones, R., Kilasara, M., Le Roux, P., Micheli, E., Montanarella, L., Spaargaren, O., Tahar, G., Thiombiano, L., Van Ranst, E., Yemefack, M. and Zougmore, R., Eds. (2013) Soil Atlas of Africa. European Commission, Luxembourg, 176.

[17] Kihara, J., Huising, J., Nziguheba, G., Waswa, B.S., Njoroge, S., Kabambe, V., Iwuafor, E., Kibunja, C., Esilaba, A.O. and Coulibaly, A. (2016) Maize Response to Macronutrients and Potential for Profitability in Sub-Saharan Africa. Nutrient Cycling in Agroecosystems, 105, 171. https://doi.org/10.1007/s10705-015-9717-2

[18] Sileshi, G.W., Debusho, L.K. and Akinnifesi, F.K. (2012) Can Integration of Legume Trees Increase Yield Stability in Rainfed Maize Cropping Systems in Southern Africa? Agronomy Journal, 104, 1392-1398. https://doi.org/10.2134/agronj2012.0063

[19] Kamanga B.C.G., Whitbread, A., Wall, P., Waddington, S.R., Almekinders, C. and Giller, K.E. (2010) Farmer Evaluation of Phosphorus Fertilizer Application to Annual Legumes in Chisepo, Central Malawi. African Journal of Agricultural Research, 5, 668-680.

[20] Kibunja Catherine, N., Ndungu-Magiroi, K.W., Wamae, D.K., Mwangi, T.J., Nafuma, L. (Deceased), Koech, M.N., Ademba, J. and Kitonyo, E.M. (2017) Optimizing Fertilizer Use within the Context of Integrated Soil Fertility Management in Kenya. In: Wortmann, C.S. and Keith, S., Eds., Fertilizer Use Optimization in Sub-Saharan Africa, CABI, Nairobi, 82-99.

[21] Senkoro, C., Ley, J.G., Marandu, A.E., Wortmann, C.S., Mzimbiri, M., Msaky, J., Umbwe, R. and Lyim, S.D. (2017) Optimizing Fertilizer Use within the Context of Integrated Soil Fertility Management in Tanzania. In: Wortmann, C.S. and Keith, S., Eds., Fertilizer Use Optimization in Sub-Saharan Africa, CABI, Nairobi, 176-191. https://doi.org/10.1079/9781786392046.0176

[22] Nalivata, P., Kibunja, C., Mutegi, J., Tetteh, F., Tarfa, B., Dicko, M.K., Ouattara, K., Cyamweshi, R.A., Nouri, M.K., Bayu, W. and Wortmann, C.S. (2017) Integrated Soil Fertility Management in Sub-Saharan Africa. In: Wortmann, C.S. and Keith, S., Eds., Fertilizer Use Optimization in Sub-Saharan Africa, CABI, Nairobi, 25-38. https://doi.org/10.1079/9781786392046.0025 
Submit or recommend next manuscript to SCIRP and we will provide best service for you:

Accepting pre-submission inquiries through Email, Facebook, LinkedIn, Twitter, etc. A wide selection of journals (inclusive of 9 subjects, more than 200 journals)

Providing 24-hour high-quality service

User-friendly online submission system

Fair and swift peer-review system

Efficient typesetting and proofreading procedure

Display of the result of downloads and visits, as well as the number of cited articles Maximum dissemination of your research work

Submit your manuscript at: http://papersubmission.scirp.org/

Or contact as@scirp.org 